\title{
Исследование влияния изгибных потерь на генерацию суперконтинуума в гольмиевых волоконных усилителях
}

\author{
И.В. Жлуктова ${ }^{1, *}$, С.А. Филатова ${ }^{1}$, Ю.Н. Пырков ${ }^{1,2}$, В.А. Камынин ${ }^{1,3}$, В.Б. Цветков ${ }^{1,4}$ \\ ${ }^{1}$ Институт общей физики им. А. М. Прохорова РАН \\ ${ }^{2}$ Московский физико-технический институт «МФТИ» \\ ${ }^{3}$ Ульяновский государственный университет \\ ${ }^{4}$ Национальный исследовательский ядерный университет «МИФИ» \\ *E-mail: iv.zhluktova@gmail.com
}

DOI:10.31868/RFL2018.108-109

Суперконтинуум (СК) в спектральном диапазоне до 3 мкм возможно использовать в разных областях: как в научных исследованиях [1], так и в практических, таких как когерентная томография [2], оптическая коммуникация [3] и др. На данный момент представлены устройства по генерации СК, построенные на высоконелинейных волокнах [4]. Однако волокна на кварцевой основе позволяют использовать стандартные сварные соединения, что делает источники СК более технологичными. Поэтому есть необходимость изучить влияние потерь на изгибах и ОН группах, как в элементах схем, так и в активных волокнах, на результирующее излучение.

В ходе исследования для регистрации излучения использовалась система синхронного детектирования, которая была сфазирована с тестовым оптическим сигналом от галогеновой лампы. Выходные спектры были получены при помощи монохроматора МДР-12. В эксперименте использовался гольмиевый волоконный усилитель, с накачкой от иттербиевого волоконного лазера на длине волны 1125 нм, и образцы гольмиевого волокна. Был промодулирован только тестовый оптический сигнал и в ходе эксперимента не регистрировалась спонтанная люминесценция. Коротковолновое излучение от галогеновой лампы отсекалось при помощи отрезающего фильтра на 1.5 мкм.

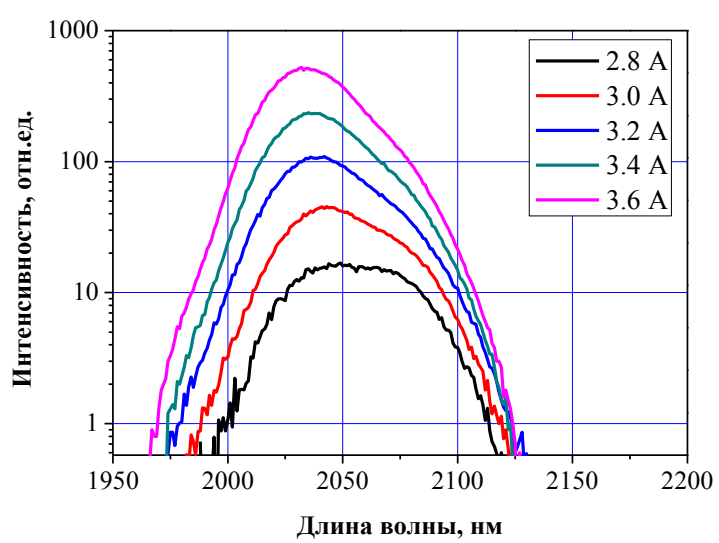

Рис.1. Спектры интенсивности выходного сигнала в логарифмическом масштабе при разных токах лазера накачки.

На рисунке 1 представлены оптические спектры интенсивности выходного сигнала гольмиевого усилителя при разных токах накачки. Из рисунка видно, что при увеличении тока лазера накачки, интенсивность люминесценции не только растёт по амплитуде, но и смещается от длинноволнового края полосы к коротковолновому. 


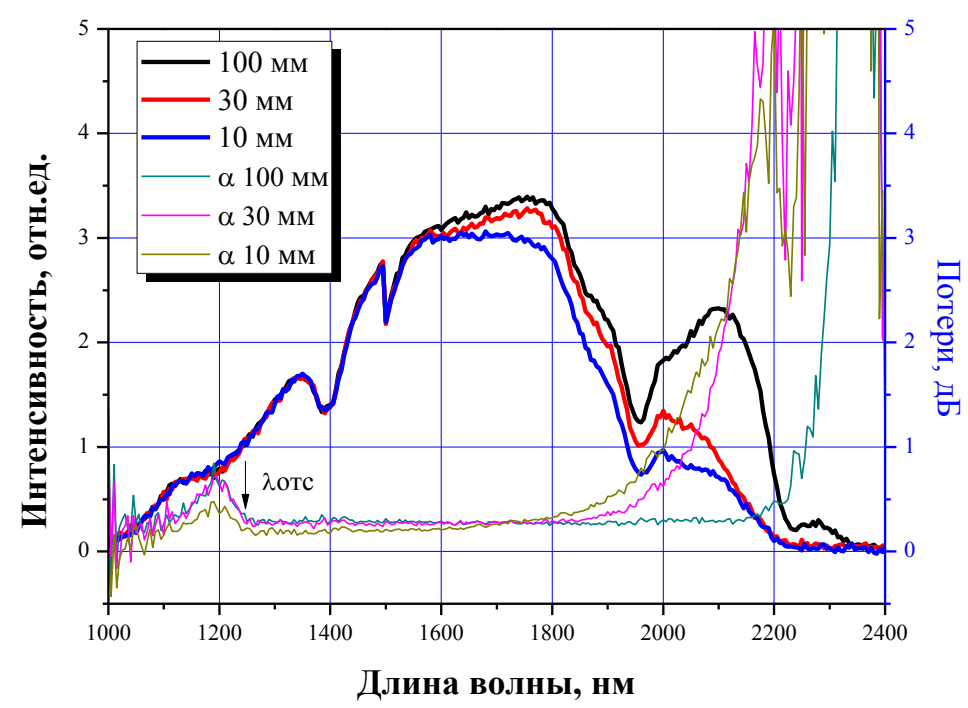

Рис.2. Оптические спектры пропускания изгибных потерь волокна, легированного $\mathrm{Ho}^{3+}$ (при разных радиусах изгиба)

Так же были проведены исследования по изгибным потерям волокна, легированного $\mathrm{Ho}^{3+}$, с поглощением на длине волны $1150 \mathrm{Hм} \sim 26$ дБ/м. Сердцевина волокна составляла 11,5 мкм с диаметром оболочки 125 мкм, числовая апертура - 0.145 , концентрация ионов $8 * 10^{19} \mathrm{~cm}^{-3}$. В ходе эксперимента образец волокна наматывался на катушки разных диаметров, и были получены спектры пропускания при различных радиусах изгиба (Рисунок 2). Как видно из рисунка 2, в спектральной области от 2 мкм с увеличением изгиба волокна уменьшается пропускная способность образца, что говорит о влиянии изгибных потерь в длинноволновой области спектра. На основе проведенных исследований, в лаборатории были реализованы источники СК, с учетом изгибных потерь для волоконного усилителя и всего устройства в целом.

Работа выполнена при поддержке Президиума Российской Академии Наук в рамках программы фундаментальных исследований № I.7 «Актуальные проблемы фотоники, зондирование неоднородных сред и материалов».

\section{Литература}

[1] R. Dorsinville, P.P. Ho et al, Springer, 377-398 (2006)

[2] I. Hartl, X.D. Li et al, Opt. Lett., 26, 608-610 (2001)

[3] H. Takara, T. Ohara et al, Elect. Lett., 41, 270-271 (2005)

[4] А.М. Желтиков., УФН, 176, 623-649 (2006). 